УДК 808.5

Е. И. Голованова

\title{
КОГНИТИВНАЯ ЭНЕРГИЯ ОБРАЗНОГО СЛОВА В СОВРЕМЕННОМ НАУЧНОМ ДИСКУРСЕ
}

\begin{abstract}
Голованова Є. І. Когнітивна енергія образного слова в сучасному науковому дискурсі.

У статті розглядаються особливості образного викладу фактів у науковому дискурсі. Автор стверджує, що при оформленні нового знання образи сприяють активізації розумової діяльності читача, служать яскравим засобом переконання, інструментом точної характеристики та інтерпретації.

Ключові слова: образ, науковий дискурс, знання, концептуалізація, інтерпретація.
\end{abstract}

Голованова Е.И. Когнитивная энергия образного слова в современном научном дискурсе.

В статье рассматриваются особенности образного изложения фактов в научном дискурсе. Автор утверждает, что при оформлении нового знания образы способствуют активизации мыслительной деятельности читателя, служат ярким средством убеждения, инструментом точной характеристики и интерпретации.

Ключевые слова: образ, научный дискурс, знание, концептуализация, интерпретация.

Golovanova E. I. Cognitive energy of the figurative word in modern scientific discourse.

In the article the features of figurative statement of facts in the scientific discourse. The author argues that the new knowledge when making images enhance mental activity of the reader, serve as a means of persuasion, an instrument precise specifications and interpretation.

Key words: image, scientific discourse, knowledge, conceptualization, interpretation.

Дискурс современного ученого немыслим без обращения к метафоре и символическому моделированию фактов, что наряду со строгими рационально-логическими построениями определяет глубину, эвристичность и научную ценность нового знания. Весьма показательно в этом отношении творчество выдающегося русского языковеда, представителя Московской лингвистической школы Михаила Викторовича Панова (1920-2001).

В работах М.В. Панова рационально-логическое и образное начала находятся в тесном взаимодействии, переплетении. Обладая развитым воображением и поэтическим даром, ученый излагает свою точку зрения на языковые факты наглядно, убедительно и емко. Блестящий пример подобного соединения научной проницательности 
ученого, его строгих рационально-логических построений и образности - статья «Об аналитических прилагательных» [4, с. 137-151].

Текст статьи предваряется эпиграфом: «Из мелкой сволочи вербую рать. А. Пушкин». Выбор столь нетривиальной цитаты из наследия классика в сочетании с использованием в ней личной конструкции и травестийным совмещением «низкого» (сволочь) и «высокого» (рать) подспудно настраивает читателя на нестандартный характер последующего изложения.

Показательно начало статьи (псевдонарратив): «Когда в языке формируется новый грамматический класс, в него стекаются самые разные по происхождению единицы, иногда - с темным, причудливым прошлым. Однако в новой грамматической общности, в новой семье их не попрекают происхождением: неважно, откуда они. Важно где». Антропоморфные образы в терминологическом окружении и обыденные сентенции служат здесь необычной формой для трансляции вполне научных фактов. После такой прелюдии - уже в следующем абзаце - автор переходит к нейтральному стилю изложения: «За последние полвека в русском литературном языке сложилась особая часть речи: аналитические прилагательные». Впрочем, полной объективности автор избегает: «Лингвисты не торопятся признать de jure этот новый лингвистический класс. Мешает в первую очередь диахроническая пелена на глазах: помнят, откуда пришли эти слова, и не видят их новых и прочных связей». Образ «пелены»» не только придает высказыванию экспрессивность, но и ясно выражает авторскую оценку событий.

С этого момента диалог автора с читателем приобретает подчеркнуто игровой характер: «Что же, проверим происхождение этой грамматической «сволочи» (сволакивается она в группу аналитприлагательных), выясним, существенно ли сегодня это прошлое. Или они уже прошли грамматическую «перековку»?» Здесь обращает на себя внимание метафора «перековки» как емкий, выразительный, точный прием указания на изменение статуса, качественной определенности того или иного объекта. К этому тексту дается сноска следующего содержания: «Далее намечены группы аналит-прилагательных по их происхождению. Современность классифицируется с диахронической точки зрения. Конечно, такая классификация не может претендовать на полную последовательность и стройность...». До этого момента текст сноски оформлен в соответствии с канонами собственно научного стиля, но далее эта каноничность разрушается: «...сквозь диахронические очки 
современность видится мутно и расплывчато» (курсив наш. - E.Г.). Вновь Панов бросает камень в огород диахронистов и негативно оценивает их способность признавать новые факты. И это, как оказалось, не в последний раз: «Извращенное сознание ультра-диахрониста может видеть в таких прилагательных приставки. Как были, так-де и остались. Эта квази-осторожность не идет на пользу дела. Действительно, по происхождению это приставки-интернационализмы. Но сейчас-то они уже псевдо-префиксы, обрели все признаки слова, а став словами, они неизбежно попадают в класс аналитических прилагательных. Какие признаки? Свободная, нефразеологическая сочетаемость с существительными (приставки-то фразеологичны! это в их природе). Сочетаемость с частицами. Фонетическая примета слова: особое персональное ударение». Если не принимать во внимание ярко выраженную диалогичность авторских построений, перед нами абсолютно логически выверенное обоснование существования аналитических прилагательных, восходящих к приставкам.

Рациональная логика и последовательность убедительно представлены и в следующем фрагменте: «Но так как единицы лже-, лесо-, хлебо- обладают свободной, не фразеологической сочетаемостью, то хлебоуборку, лесозаготовки и следует признать лжесловами: в современном языке это уже словосочетания, словосоположения, слово-, так сказать, -кортежи, последовательности». На фоне нейтрального стиля весьма неожиданно употребление окказионализмов (словосоположения, словокортежи) и - в дальнейшем тексте - образных комментариев: «Полумертвая группа» (о словах, начинающихся с зауряд-: заурядпоручик, зауряд-офищер и под.). И в этом же контексте: «Были устойчивые сочетания: баба-жох, парень-хват <... П. Произошло - хотя бы и в речи - освобождение этих закрепленных привесков от фразеологических цепей» («освобождение от цеепей» - явная аллюзия к текстам революционной эпохи).

Интересен комментарий ученого к 17-й группе прилагательных (тоже-лингвисты, тоже-политики): «Редкий (единичный?) случай, когда частица (вообще: служебное слово) становится аналитическим прилагательным. Пожалуй, это уже факт языка. Не вродеприлагательное, а настоящее. Конечно, аналитическое». Автору не откажешь в логике, с одной стороны, и в словотворчестве, словесной игре (вроде-прилагательное) - с другой.

«Морфемы (приставки, части сложных слов) ведут себя как части фразеологизма: значение их варьируется в разных словах так, 
что предсказать тот семантический кунштюк, который выкинет слово в данном контексте - в данном слове, в сочетании с такими-то морфемными соседями, - как правило, невозможно. Лишь только часть слова становится семантически стабильна в сочетании с любой единицей данного типа, она перестает быть частью слова. Она дорастает до отдельного слова. Так и появляются многие аналитприлагательные (выделено нами. - E. Г.)». На фоне общеязыковых метафор (ведут себя - о морфемах) в данном фрагменте появляется малопонятное «кунштюк», которое «выкинет слово», «соседи» - все это разрушает автоматизм восприятия научного текста и придает ему особый, условно-игровой характер.

Неожиданными оказываются и ответы автора на «виртуальные» реплики оппонентов: «Для многих аналитические прилагательные это «фи!» слова, неполноценные однодневки. Но день-то оказался долог - и, видимо, будет длиться и длиться».

Замечателен конец статьи, где излагается, по сути, кредо Панова: «Даже и сейчас эти преграды мешают лингвисту аналитические прилагательные признать аналитическими прилагательными. Как же трудно было в первый раз установить их особый грамматический статус! Отделить их от похожего, но качественно иного! Здесь нужна раскованность и широта теоретической мысли, нужны проницательность и умение, отойдя от «кажимости», понять суть сложного и движущегося новшества в языке, нужна смелость в преодолении ложных лингвистических традиций и еще большая смелость в создании новых. Строгое испытание для лингвиста - эти аналитические прилагательные.

А ведь, казалось бы, простая вещь».

В приведенном фрагменте автор, начав с парадоксального высказывания, переходит к эмоционально-напряженному монологу, с высокой патетикой, ритмизованным синтаксисом, повторами, и далее неожиданно «переключает» стилевой код, ослабляя напряжение, «снижая» пафос контекста до почти обыденного комментария. Как видим, перед нами не просто научная статья, перед нами научнохудожественный текст, где гармонично переплелись черты науки и искусства. Судя по всему, «раскованность и широта теоретической мысли» как раз и свойственны тем ученым, которые обладают не только развитым рационально-логическим мышлением, но и неординарным интуитивно-творческим, образным началом (см.: [1]). В большей или меньшей степени последнее проявляется во всех 
научных работах М. В. Панова.

Факты и закономерности языка предстают под пером исследователя в человеческом обличье: они испытывают чувства, эмоции, вступают в разнообразные отношения между собой. Ср.: «Дальнейшее исследование ее (диэремы. - Е. Г.) причуд и капризов не может не быть важно и плодотворно для общей фонологической теории» [4, с. 319]; «Почти у каждого звонкого есть приятель глухой согласный» [2, с. 54]; «...перед мягким зубным другой зубной непременно смягчается. Другими словами, первый звук находится в зависимости от обстановки, окружения, на него бросает тень сосед» [2, с. 56]; «один звук приноравливается к другому», «Фонема $[\gamma]$ (г фрикативное), когда-то чувствовавшая себя вполне уверенно, cходит на нет» [3, с. 28]; «Гласный, попав в неблагоприятную для него позицию, не всегда умеет за себя постоять» [3, с. 29]; «Такова первая особенность литературной нормы: эта норма-“однолюб”» [4, с. 91]; «У литературной речи есть удивительная, нежданная черта: способность усыновлять нелитературные отрезки текста» [4, с. 99].

Метафорическое моделирование применяется М.В.Пановым как для репрезентации уже отрефлексированного опыта, так и для концептуализации нового научного знания. При оформлении нового знания образы способствуют активизации мыслительной деятельности читателя, служат средством убеждения, инструментом характеристики и интерпретации.

В целом, эвристическое переживание языка, эмоции, стихия эксперимента и игры - характерные черты дискурса М. В. Панова, отражающие особенности его личности. Однако эти особенности постепенно становятся общими в филологическом дискурсе начала XXI века.

\section{Литература}

1. Голованова $\quad$ Е. И. Профессиональная языковая личность: специфика познавательных процессов в сфере теории и практики / Елена Иосифовна Голованова // Non multum, sed multa: Немного о многом. У когнитивных истоков современной терминологии : сб. науч. тр. в честь В. Ф. Новодрановой. - М. : Авторская академия, 2010. - C. 261-270.

2. Панов М. В. И все-таки она хорошая. Рассказ о русской орфографии / Михаил Викторович Панов. - М. : Наука, 1964. - 167 с.

3. Панов М. В. История русского литературного произношения XVIII-XX вв. / Михаил Викторович Панов. - М. : Наука, 1990. - 456 с.

4. Панов М. В. Труды по общему языкознанию и русскому языку : в 2 т. / под ред. Е. А. Земской, С. М. Кузьминой. - Т. 1. - М. : Языки славянской культуры, 2004. $568 \mathrm{c}$. 